\title{
Growing Conditions and Growth Parameter Influences the Softwood Grafting in Tamarind (Tamarindus indica L.)
}

\author{
R. Praveenakumar*, R. Vasantha Kumari, B.G. Hanumantharaya and C. Suneetha \\ Department of Horticulture, GKVK, University of Agricultural Sciences, \\ Bangalore-560065, India \\ *Corresponding author
}

\section{A B S T R A C T}

\section{Keywords}

Sprout emergence, Number of leaves, Number of sprouts, Softwood, Grafting

Article Info

Accepted:

12 January 2019

Available Online:

10 February 2019
An investigation was carried out to growing condition and growth parameter of softwood grafting in Tamarind under low cost polyhouse, shade net and open field conditions during 2017-18 at monthly interval of February to May 2017. The experiment was laid out with three replications comprising of four treatments. The data were statistically analysed by split plot design. The result relevant that least numbers days taken for sprout emergence $\mathrm{T}_{4}$ $\left(\mathrm{M}_{2} \mathrm{C}_{1}\right.$ : March + low cost poly house) (18.88), maximum number of sprouts $\mathrm{T}_{6}\left(\mathrm{M}_{2} \mathrm{C}_{3}\right.$ : March + shade net) (12.70), maximum number of leaves per graft as observed $\mathrm{T}_{4}\left(\mathrm{M}_{2} \mathrm{C}_{1}\right.$ : March + low cost polyhouse) (30.66), height number of branches $\mathrm{T}_{4}\left(\mathrm{M}_{2} \mathrm{C}_{1}\right.$ : March + low cost polyhouse) (8.66), highest graft diameter observed in $\mathrm{T}_{4}\left(\mathrm{M}_{2} \mathrm{C}_{1}\right.$ : March + low cost polyhouse) (0.94) and maximum number of chlorophyll content per graft as observed $\mathrm{T}_{4}$ $\left(\mathrm{M}_{2} \mathrm{C}_{1}\right.$ : March + low cost polyhouse) (39.66), maximum results are obtained under treatment of $\mathrm{T}_{4}\left(\mathrm{M}_{2} \mathrm{C}_{1}\right.$ : March + low cost polyhouse $)$.

\section{Introduction}

Tamarind (Tamarindusindica L.), a member of subfamily Caesalpiniaceae of family Fabaceae, is an underutilized fruit and widely distributed throughout tropic and sub-tropics as stray plantation or avenue. It is a source of timber, fruits, seeds, fodder, medicinal extracts and has potential of industrial use (Dwivedi et al., 1990). It is highly heterozygous, cross-pollinated fruit crop and as such seedlings exhibit a wide range of variations, which aids in the selection of the superior desirable genotypes. Due to cross pollination and Predomination practice of seed propagation, there is immense opportunity to locate elite trees having desirable horticultural traits, which needs to be conserved and exploited (Keskar et al., 1989; Pathak et al., 1992 and Karale et al., 1999). Despite its varied advantages, it could not attract suitable scientific attention towards its propagation. True-to-the-type propagules could be multiplied from elite trees that produce good quality fruits only by asexual methods. Of various propagation methods, grafting and budding are of paramount importance in tropical and subtropical fruit 
trees as they result in high success and field establishment. The time and method are considered to be the most vital factor that determines the success and establishment of the grafts.

Systematic information in this regard is scanty particularly under harsh semi-arid ecosystem for tamarind. Therefore, the present investigation was undertaken to standardize method and time of propagation and different conditions of grafting in tamarind under Eastern dry zone of Karnataka.

\section{Materials and Methods}

The experiment was conducted at Division of Horticulture, University of Agricultural Sciences, Bengaluru during 2017 (February to May) It is situated at an elevation of $830 \mathrm{~m}$ above the mean sea level, at $121^{\circ} 58^{\prime}$ north latitude and $77^{\circ} 35^{\prime}$ east longitude. The annual mean relative humidity of location is 85.6 per cent. The minimum and maximum temperature in a year ranges between $17.4^{\circ} \mathrm{C}$ and $37^{\circ} \mathrm{C}$ respectively. The average rainfall was about $930 \mathrm{~mm}$. The experiments were carried out with the main objectives of studies on softwood grafting techniques using low cost poly house, shade net and open field condition facilities. To raise the nursery, fresh seeds were sown in a seed pan for germination. When seedlings attained four leaf stages they were transplanted to polyethylene bags containing a potting mixture of red sandy loam soil, sand and farm yard manure in the ratio of 3:1:1, respectively. The seedlings were grown for one year and softwood grafting during four different months softwood grafting over the year was done with scion procured from 10 years old healthy tamarind tree. The vegetative growth such as sprouting and leaf emergence of graft success and survival per cent was recorded at 60 and 90 days after softwood grafting of tamarind.

\section{Results and Discussion}

The least number of sprout emergence was recorded in the month of March $\left(\mathrm{M}_{2}\right)$ (20.47), low cost polyhouse $\left(\mathrm{C}_{1}\right)$ (20.46) (Table 1) because of favorable climatic conditions like high relative humidity and increase in translocation of food materials. Similar results were reported by Mohammad and Mohammad (2005).

Maximum number of sprout was recorded in the month of March $\left(\mathrm{M}_{2}\right)$ (12.02), shade net $\left(C_{3}\right)$ (9.97) (Table 1) because of favorable climatic conditions like high relative humidity and increase in translocation of food materials. This may be due to the favorable climatic conditions during these months such as moderate temperature $\left(28^{\circ} \mathrm{C}\right.$ to $\left.32^{\circ} \mathrm{C}\right)$ and ideal relative humidity $(74 \%$ to $78 \%)$. The temperature and relative humidity activates the cambium cells during monsoon. The new callus tissue arising out of the cambial region consists of thin walled turgid cells which are easily desiccated and die off due to dry weather and higher relative humidity can protect such cells in the cambial region of the graft union (Hartaman and Kester, 1989). Minimum number of the days for sprouting after grafting was also recorded by recorded Hulamani and Nachegowda (1981) in mango. This might also be attributed to the fact that easy swelling of buds (both axillary and apical) which would have caused quick healing of union, leading to the better sprouting of grafts.

The height number of leaves $(25.01,22.68)$ was found under the March $\left(\mathrm{M}_{2}\right)$, shade net $\left(\mathrm{C}_{3}\right)$ respectively (Table 2 ). Could also be correlated to higher cell activity and active growth of both stock and scion in the prevailing favourable climatic condition. Pawaret al., (2003) in custard apple and Ghojageet al., (2011) in jamun recorded the same results. 
The height number of branches $(7.15,6.50)$ under the month of March $\left(\mathrm{M}_{2}\right)$, low cost polyhouse $\left(\mathrm{C}_{1}\right)$ respectively (Table 2 ). This could be due to favorable climatic condition like high relative humidity and increase in translocation of food material. Similar results were reported by Mohammad and Mohammad, (2005).

Table.1 Influence of the months of grafting, growing condition and their interaction on days taken for first sprout emergence (days)and number of sprouts of Tamarind after 60 days of grafts

\begin{tabular}{|c|c|c|}
\hline Treatments & $\begin{array}{c}\text { Days taken for first sprout } \\
\text { emergence }\end{array}$ & Number of sprout \\
\hline \multicolumn{3}{|c|}{ MONTHS (M) } \\
\hline$M_{1}$ - February & 22.15 & 9.51 \\
\hline $\mathbf{M}_{2}$-March & 20.47 & 12.02 \\
\hline $\mathbf{M}_{3}$-April & 22.94 & 8.53 \\
\hline M-May & 24.31 & 6.84 \\
\hline$F$ test $(p \leq 0.05)$ & * & * \\
\hline S.Em \pm & 0.11 & 0.15 \\
\hline C.D at 5\% & 0.41 & 0.55 \\
\hline \multicolumn{3}{|c|}{ CONDITION(C) } \\
\hline$C_{1}$-Low cost polyhouse & 20.46 & 11.88 \\
\hline $\mathrm{C}_{2}$ - Open field & 24.46 & 5.82 \\
\hline $\mathrm{C}_{3}$ - Shade net & 22.62 & 9.97 \\
\hline$F$ test $(p \leq 0.05)$ & $*$ & * \\
\hline S.Em \pm & 0.08 & 0.22 \\
\hline C.D at $5 \%$ & 0.24 & 0.68 \\
\hline \multicolumn{3}{|c|}{ INTERACTION $(\mathrm{M} \times \mathrm{C})$} \\
\hline $\mathbf{M}_{1} \mathbf{C}_{1}$ & 20.23 & 12.30 \\
\hline $\mathbf{M}_{1} \mathbf{C}_{2}$ & 25.02 & 06.50 \\
\hline $\mathrm{M}_{1} \mathrm{C}_{3}$ & 23.36 & 9.66 \\
\hline $\mathbf{M}_{2} \mathbf{C}_{1}$ & 18.88 & 16.00 \\
\hline $\mathbf{M}_{2} \mathbf{C}_{2}$ & 22.63 & 7.30 \\
\hline $\mathbf{M}_{2} \mathrm{C}_{3}$ & 20.04 & 12.70 \\
\hline $\mathbf{M}_{3} \mathbf{C}_{1}$ & 20.26 & 10.26 \\
\hline $\mathrm{M}_{3} \mathrm{C}_{2}$ & 24.53 & 5.73 \\
\hline $\mathbf{M}_{3} \mathbf{C}_{3}$ & 22.86 & 9.60 \\
\hline$M_{4} C_{1}$ & 22.60 & 8.93 \\
\hline $\mathbf{M}_{4} \mathbf{C}_{2}$ & 26.06 & 3.73 \\
\hline $\mathrm{M}_{4} \mathrm{C}_{3}$ & 24.26 & 7.86 \\
\hline$F$ test $(p \leq 0.05)$ & * & * \\
\hline S.Em \pm & 0.17 & 0.39 \\
\hline C.D at $5 \%$ & 0.57 & 1.23 \\
\hline
\end{tabular}

*Significant

T1- M1C1: February + Low cost polyhouse

T2- M1C2: February + open field

T3- M1C3: February + Shadenet

T4- M2C1: March + Low cost polyhouse

T5- M2C2: March + Open field

T6- M2C3: March +Shadenet
T7- M3C1: April + Low cost Polyhouse

T8- M3C2: April+Open field

T9- M3C3: April+Shadenet

T10- M4C1: May + Low cost Polyhouse

T11- M4C2: May + Open field

T12- M4C3: May + Shadenet 
Table.2 Influence of the months of grafting, growing condition and their interaction on number of leaves and number of branches of Tamarind after 60 days of grafts

\begin{tabular}{|c|c|c|}
\hline Treatments & Number of leaves & Number of branches \\
\hline \multicolumn{3}{|c|}{ MONTHS (M) } \\
\hline$M_{1}$ - February & 22.11 & 5.11 \\
\hline $\mathbf{M}_{2}$-March & 25.01 & 7.15 \\
\hline $\mathbf{M}_{3}$-April & 20.31 & 4.35 \\
\hline $\mathrm{M}_{4}$-May & 16.55 & 3.30 \\
\hline$F$ test $(p \leq 0.05)$ & $*$ & $*$ \\
\hline S.Em \pm & 0.29 & 0.18 \\
\hline C.D at $5 \%$ & 1.04 & 0.66 \\
\hline \multicolumn{3}{|c|}{ CONDITION(C) } \\
\hline $\mathrm{C}_{1}$-Low cost polyhouse & 25.66 & 6.50 \\
\hline $\mathrm{C}_{2^{-}}$Open field & 14.63 & 3.23 \\
\hline $\mathrm{C}_{3}$ - Shade net & 22.68 & 5.26 \\
\hline$F$ test $(p \leq 0.05)$ & $*$ & $*$ \\
\hline S.Em \pm & 0.34 & 0.08 \\
\hline C.D at $5 \%$ & 1.05 & 0.26 \\
\hline \multicolumn{3}{|c|}{ INTERACTION $(\mathrm{M} \times \mathrm{C})$} \\
\hline $\mathbf{M}_{1} \mathbf{C}_{1}$ & 27.66 & 7.01 \\
\hline $\mathbf{M}_{1} \mathbf{C}_{2}$ & 14.33 & 3.33 \\
\hline $\mathbf{M}_{1} \mathbf{C}_{3}$ & 24.33 & 5.45 \\
\hline $\mathrm{M}_{2} \mathrm{C}_{1}$ & 30.66 & 8.66 \\
\hline $\mathbf{M}_{2} \mathbf{C}_{2}$ & 17.66 & 4.66 \\
\hline $\mathbf{M}_{2} \mathbf{C}_{3}$ & 26.66 & 8.13 \\
\hline $\mathrm{M}_{3} \mathrm{C}_{1}$ & 23.93 & 5.73 \\
\hline $\mathbf{M}_{3} \mathbf{C}_{2}$ & 16.22 & 2.83 \\
\hline$M_{3} C_{3}$ & 21.44 & 4.05 \\
\hline $\mathbf{M}_{4} \mathrm{C}_{1}$ & 20.43 & 4.66 \\
\hline $\mathrm{M}_{4} \mathrm{C}_{2}$ & 10.53 & 2.10 \\
\hline $\mathrm{M}_{4} \mathrm{C}_{3}$ & 18.73 & 3.43 \\
\hline F test $(p \leq 0.05)$ & $*$ & $*$ \\
\hline S.Em \pm & 0.60 & 0.23 \\
\hline C.D at $5 \%$ & 2.00 & 0.70 \\
\hline
\end{tabular}

*Significant

T1- M1C1: February + Low cost polyhouse

T2- M1C2: February + open field

T3- M1C3: February + Shadenet

T4- M2C1: March + Low cost polyhouse

T5- M2C2: March + Open field

T6- M2C3: March +Shadenet
T7- M3C1: April + Low cost Polyhouse

T8- M3C2: April+Open field

T9- M3C3: April+Shadenet

T10- M4C1: May + Low cost Polyhouse

T11- M4C2: May + Open field

T12- M4C3:May + Shadenet 
Table.3 Influence of the months of grafting, growing condition and their interaction on scion diameter and SPAD (chlorophyll content) of Tamarind after 60 days of grafts

\begin{tabular}{|c|c|c|}
\hline Treatments & Scion diameter & SPAD (Chlorophyll content) \\
\hline \multicolumn{3}{|c|}{ MONTHS (M) } \\
\hline$M_{1}$ - February & 0.88 & 32.58 \\
\hline $\mathbf{M}_{2}$-March & 0.91 & 34.15 \\
\hline $\mathbf{M}_{3}$-April & 0.84 & 33.11 \\
\hline $\mathbf{M}_{4}$-May & 0.79 & 30.00 \\
\hline$F$ test $(p \leq 0.05)$ & $*$ & $*$ \\
\hline S.Em \pm & 0.002 & 0.30 \\
\hline C.D at $5 \%$ & 0.009 & 1.07 \\
\hline \multicolumn{3}{|c|}{ CONDITION(C) } \\
\hline $\mathrm{C}_{1}$-Low cost polyhouse & 0.88 & 37.83 \\
\hline $\mathrm{C}_{2^{-}}$Open field & 0.81 & 26.11 \\
\hline $\mathrm{C}_{3}$ - Shade net & 0.85 & 33.05 \\
\hline$F$ test $(p \leq 0.05)$ & $*$ & $*$ \\
\hline S.Em \pm & 0.002 & 0.26 \\
\hline C.D at $5 \%$ & 0.006 & 0.78 \\
\hline \multicolumn{3}{|c|}{ INTERACTION $(\mathbf{M} \times \mathbf{C})$} \\
\hline $\mathbf{M}_{1} \mathbf{C}_{1}$ & 0.92 & 37.06 \\
\hline $\mathbf{M}_{1} \mathbf{C}_{2}$ & 0.84 & 26.00 \\
\hline $\mathbf{M}_{1} \mathbf{C}_{3}$ & 0.86 & 34.70 \\
\hline $\mathbf{M}_{2} \mathbf{C}_{1}$ & 0.94 & 39.66 \\
\hline $\mathrm{M}_{2} \mathrm{C}_{2}$ & 0.87 & 27.33 \\
\hline $\mathbf{M}_{2} \mathbf{C}_{3}$ & 0.90 & 33.40 \\
\hline $\mathrm{M}_{3} \mathrm{C}_{1}$ & 0.88 & 37.60 \\
\hline $\mathrm{M}_{3} \mathrm{C}_{2}$ & 0.78 & 27.66 \\
\hline $\mathrm{M}_{3} \mathrm{C}_{3}$ & 0.85 & 35.13 \\
\hline $\mathrm{M}_{4} \mathrm{C}_{1}$ & 0.80 & 36.00 \\
\hline $\mathrm{M}_{4} \mathrm{C}_{2}$ & 0.76 & 23.46 \\
\hline $\mathrm{M}_{4} \mathrm{C}_{3}$ & 0.79 & 29.00 \\
\hline$F$ test $(p \leq 0.05)$ & $*$ & $*$ \\
\hline S.Em \pm & 0.004 & 0.52 \\
\hline C.D at $5 \%$ & 0.013 & 1.67 \\
\hline
\end{tabular}

*Significant

T1- M1C1: February + Low cost polyhouse

T2- M1C2: February + open field

T3- M1C3: February + Shadenet

T4- M2C1: March + Low cost polyhouse

T5- M2C2: March + Open field

T6- M2C3: March +Shadenet
T7- M3C1: April + Low cost Polyhouse

T8- M3C2: April+Open field

T9- M3C3: April+Shadenet

T10- M4C1: May + Low cost Polyhouse

T11- M4C2: May + Open field

T12- M4C3: May + Shadenet
Maximum number of scion diameter observed $(0.91,0.88)$ under the month of March $\left(\mathrm{M}_{2}\right)$, low cost polyhouse $\left(\mathrm{C}_{1}\right)$ respectively (Table 3). Plants might be attributed to favorable growing conditions with enhanced $\mathrm{CO}_{2}$ assimilation as compared to plants under open field condition, which increases the rate of photosynthesis leads to formation of more photosynthesis that facilitates the increases in scion diameter, similar results were obtained 
by (Syamal et al., 2012) in guava and (Syamal et al., 2013) in beal.

The highest SPAD (Chlorophyll content) (345.15 $\mu$ mol per $\mathrm{m}^{2}, 37.83 \mu \mathrm{mol}$ per $\mathrm{m}^{2}$ ) was found under the March $\left(\mathrm{M}_{2}\right)$, low cost polyhouse $\left(\mathrm{C}_{1}\right)$, respectively (Table 3$)$. SPAD reading is higher in low cost polyhouse compared to shade net and open field conditions. Under the polyhouse conditions, about 75 percentage of sun light were expected, graft canopy with higher or optimum temperature which result in higher metabolic rate and therefore chlorophyll condition. But chlorophyll content is poor in shade net, similarly under the open condition the quantum of light could be high that results in yellowing of leaves (Richard et al., 1990).

\section{References}

Dwivedi, K., Ali, Wahid and Pathak, R.K. 1990. Effect of sodicity on growth and mineral content of tamarind (Tamarindus indica L.). Ann. Agril. Res. 17: 447-49.

Ghojage, A. H., Swamy, G. S. K., Kanamadi, V. C., Jagdeesh, R. C., Kumar, P. C., Patil, P. and Reddy, B. S., 2011, Effect of season on softwood grafting in jamun (Syzygiumcumini, Skeels.) ActaHort, Pp. 890.

Hartamann, H. T. and Kester, D. E., 1989, Plant Propagation Principles and practices fifth Edn., Prentice Hall Ltd., pp. 360-363.

Hulamani, N.C. and Nachegowda, N., 1981, Studies on green wood wedge grafting in some varieties of mango. The Lalbagh, 25(2): 77-79.
Karale, A.R., Wagh, A.P., Pawar, B.G. and More, T.A. 1999. Association of fruit characters in tamarind. J. Maharashtra Agril. Univ. 24: 319-20.

Keskar, B.G., Karale, A.R., Dhawale, B.C. and Chaudhary, K.G. 1989. Improvement of tamarind by selection. Maharashtra J. Hort.4: 121-24.

Mohammad HM, and Mohammad AFF, Studies On Effect Of Some Bio Fertilizer Of Growth Of Peach Seedling And Root Disease Incidence. Egypet. J. Hort., (2005); 26(1): 7-18.

Pathak, R.K., Ojha, C.M. and Dwivedi, R. 1992. Adopt patch budding for quicker multiplication in tamarind. Indian Hort.36: 17.

Pawar D. M, Ingle V. G. and Panchabhai D. M. 2003, Effect of age of rootstock and time of grafting on success of soft wood grafts of custard apple under local conditions. Ann. Plant Physiol.; 17: 5355.

Richard, J., Campbell, Kendrick, N., Mobley, Richard, P., Marini, And Douglas, G. P., 1990, Growing Conditions Alter the Relationship between SPAD-501 Values and Apple Leaf Chlorophyll. Hort. Sci., 25(3): 330-331.

Symal, M. M., Ranjeet, and Mamath, J., 2012, Performance Of Wedge Grafting In Guava Under Different Growing Conditions. Indian J. Horti., 69(3): 424427.

Symal, M.M., Maurya, V. K. and Joshi, M., 2013, Effect of methods and time of propagation in beal in guava under different growing conditions. Indian $J$. Horti., 70(1): 124-127.

\section{How to cite this article:}

Praveenakumar, R., R. Vasantha Kumari, B.G. Hanumantharaya and Suneetha, C. 2019. Growing Conditions and Growth Parameter Influences the Softwood Grafting in Tamarind (Tamarindus indica L.). Int.J.Curr.Microbiol.App.Sci. 8(02): 1530-1535. doi: https://doi.org/10.20546/ijcmas.2019.802.178 